\title{
The Most Ancient Greek Manuscripts of the Ladder of John Climacus
}

\author{
Tatiana G. Popova
}

Severodvinsk branch of the Northern Arctic Federal University, Arkhangelsk, Russia

lestvic@mail.ru

\begin{abstract}
The Byzantine hand-written tradition of the Ladder of Divine Ascent has poorly been studied. The first step in this direction should be the systematic description of all surviving Greek manuscripts of this book. According to the counting of the author, not less

* Abbreviations: $E B E$ - collection of manuscripts of the National Library of Greece (Athens); EBE Met. - collection of manuscripts Metochion tou panagiou Taphou (Athens, EBE); RNB collection of Greek manuscripts of the National Library of Russia (Saint Petersburg, fund 9o6); Bar. - collection of manuscripts of Giakomo Barocci (Oxford, Bodleian Library); Conv. Soppr. - collection of manuscripts of Conventi Soppressi (Florence, Laurentian Library); Dem. - collection of manuscripts of the Skete of Saint Demetrius (Mount Athos, Vatopedi); Grott. - collection of manuscripts of the monastery Grottaferrata (Italy); Iber. - collection of manuscripts of the monastery Iviron (Athos); Jer. Saba - collection of manuscripts of the Holy Labra of Saint Sabbas (Jerusalem, The Library of Greek Orthodox Church); Karak. - collection of manuscripts of the monastery Karakallou (Athos); Kutl. - collection of manuscripts of the monastery Koutloumousiou (Athos); Lond. - collection of manuscripts of the British Library (London); Met. Metam. - collection of manuscripts of the Holy Monastery of Great Meteoron (Meteora); Mil. - collection of manuscripts of the Biblioteca Ambrosiana (Milan); Paris - collection of manuscripts of the National Library of France (Paris); Plut. - collection of manuscripts Plutei (Florence, Laurentian Library); Sin. N. - A New collection of Sinai (Saint Catherine's Monastery); Sin. gr. - collection of manuscripts of the Saint Catherine's Monastery (Sinai); Sinod. gr. - Synodal collection of Greek manuscripts of the State Historical Museum (Moscow); Tor. - collection of manuscripts of the National and University Library (Turin); Urb. - collection of manuscripts Urbani of the Franzoniana Library (Gevoa); Vat. Chig. gr. collection of manuscripts Chigi graeci (Vatican City, Apostolic Library); Vat. Palat. gr. - collection of manuscripts Palatini graeci (Vatican City, Apostolic Library); Ven. - collection of manuscripts of the Biblioteca Marciana (Venice); Wolf. Gud. gr. - collection of manuscripts Gudiani graeci of the Herzog August Library (Wolfenbuettel).
\end{abstract}


than 511 Greek manuscripts from the eighth to the nineteenth century with text of the Ladder were kept. This article is dedicated to the 35 most ancient books, dated from 8th to 1oth century. The most ancient Greek manuscripts of the Ladder are available in the libraries of not less than 8 countries (Italy, Greece, Egypt, Russia, England, Germany, France and Israel (Jerusalem).

\section{Keywords}

Byzantine monasticism - manuscripts - libraries - Ladder of Divine Ascent - John Climacus

One of literary monuments, which had huge influence on whole European culture, is the treatise written by the abbot of Sinai Monastery John in the early seventh century. In the Christian world it became widely known under the name Klimax (Scala paradisi, Ladder of Divine Ascent, Jncmвuua etc.). The Byzantine hand-written tradition of the monument has been studied rather poorly. The first step in this direction should be the identification and the systematic description of all surviving Greek manuscripts of this book.

The question about the quantity of surviving Greek manuscripts is open. The first scientist, who named an exact number of manuscripts, was Dmitrii Bogdanović. In his monograph the researcher gave a chronological list of the 78 Greek books from the ninth to the seventeenth century. ${ }^{1}$ This list can sometimes be complemented. In 2010 the number of Greek manuscripts known to me was 123 books, ${ }^{2}$ in 2011 - 180 books. ${ }^{3} 627$ manuscripts appear in the electronic database Pinakes of the Institut de recherche et d'histoire des textes (<http://pinakes.irht.cnrs.fr>), but many books are repeated two or even three times, the information about the books is given briefly and dating is often incorrect. So, for example, the manuscript Jer. Saba 605 is named in this database as the Ladder, but in fact this manuscript represents a Sammelband (convolutus), in one part of which there are fragments from the Ladder. ${ }^{4}$

1 Д. Богдановић.Јован Лествичникувизантијској и старој српској књижевности. Београд, 1968, app. 1.

2 Т. Г. Попова, Славянская рукописная традииия Лествиџы Иоанна Синайского, Северодвинск, 2010, pp. 272-275.

3 Т. Г. Попова, Лествица Иоанна Синайского в славянской книжности, Saarbrücken, 2o11, pp. 429-434.

4 S.J.Voicu, S. D’Alisera, Index in manuscriptorum graecorum edita specimina, Roma, 1981, p. 327. 
The database Pinakes is doubtlessly, a great help for researchers, but its information needs to be verified. So, from 627 significant manuscripts of the Ladder in this database 505 really exist. On the other hand 6 Greek manuscripts of the Ladder are absent. According to my countings, not less than 511 Greek manuscripts from the eighth to the nineteenth century with text of the Ladder were kept. Chronologically, the Greek manuscripts are distributed as following: of the eighth century not less than 2 books were kept, of the ninth century - not less than 4 , of the tenth century - not less than 29 , of the eleventh century not less than 68 , of the twelfth century - not less than 63 , of the thirteenth century - not less than 79, of the fourteenth century - not less than 142, of the fifteenth century - not less than 39, of the sixteenth century - not less than 49, of the seventeenth century - not less than 24 , of the eighteenth century - not less than 7 and of the nineteenth century - not less than 5 . Thus, it is obvious, that the peak of popularity of the Byzantine Ladder fell on the fourteenth century, on the period of hesychasm disputes.

This article is dedicated to the set of 35 most ancient books, dated by 8th1oth century.

No. Dating Storage Signature

\begin{tabular}{|c|c|c|c|}
\hline 1. & 8th cent. & Italy, Milan, Biblioteca Ambrosiana & Mil. $B 117$ sup. \\
\hline 2. & 8th cent. & $\begin{array}{l}\text { Egypt, Mount Sinai, Saint Catherine's } \\
\text { Monastery }\end{array}$ & $\operatorname{Sin} . N .71$ \\
\hline 3 . & 899 (24 May) & $\begin{array}{l}\text { Russia, Moscow, State Historical } \\
\text { Museum }\end{array}$ & Sinod.gr. 145 \\
\hline 4. & 9th cent. & Italy, Vatican City, Apostolic Library & Vat. Palat. gr. 49 \\
\hline 5 . & $9^{\text {th cent. }}$ & $\begin{array}{l}\text { Germany, Wolfenbuettel, Herzog August } \\
\text { Library }\end{array}$ & Wolf. Gud.gr. 41. \\
\hline 6. & $9-1$ oth cent. & $\begin{array}{l}\text { Egypt, Mount Sinai, Saint Catherine's } \\
\text { Monastery }\end{array}$ & Sin.gr. 416 \\
\hline 7 . & 948 & England, Oxford, Bodleian Library & Bar. 134 \\
\hline 8. & $\begin{array}{l}\text { First half of the } \\
\text { 1oth cent. }\end{array}$ & $\begin{array}{l}\text { Greece, Mount Athos, Monastery of } \\
\text { Iviron }\end{array}$ & Iber. 1434 \\
\hline 9 . & $\begin{array}{l}\text { First half of the } \\
\text { 1oth cent. }\end{array}$ & $\begin{array}{l}\text { Egypt, Mount Sinai, Saint Catherine's } \\
\text { Monastery }\end{array}$ & Sin. gr. 421 \\
\hline 10. & Middle 1 oth cent. & $\begin{array}{l}\text { Russia, Moscow, State Historical } \\
\text { Museum }\end{array}$ & Sinod.gr. 362 \\
\hline 11. & $95^{8}$ & $\begin{array}{l}\text { Greece, Mount Athos, Karakallou } \\
\text { monastery }\end{array}$ & Karak. 29 \\
\hline 12. & 969 & $\begin{array}{l}\text { Greece, Meteora, The Holy Monastery of } \\
\text { Great Meteoron }\end{array}$ & Met. Metam. $5^{65}$ \\
\hline
\end{tabular}


No. Dating

13. 985 (31 January) Iviron

14. 992

15. Late 1oth cent.

16. 1oth cent.

17. 1oth cent.

18. 1oth cent.

19. 1oth cent.

20. 1oth cent.

21. 1oth cent.

22. 1oth cent.

23. 1oth cent.

24. 1oth cent.

25. 1oth cent.

26. 1oth cent.

27. 1oth cent.

28. 1oth cent.

29. 1oth cent.

3o. 1oth cent.

31. 1oth cent.

32. 1oth cent.

33. Late 1oth cent. - early 11 th cent.

34. Late 1oth cent. Italy, Florence, Laurentian Library - early 11 th cent.

35. Late 1oth cent. Italy, Grottaferrata monastery - early 11 th cent.
Storage

Russia, Moscow, State Historical

Museum

France, Paris, National Library of France

Greece, Athens, National Library of

Greece

Greece, Athens, National Library of

Greece

Greece, Athens, National Library of

Greece

Russia, Saint Petersburg, National

Library of Russia

Italy, Florence, Laurentian Library

Greece, Mount Athos, the Skete of Saint

Demetrius

Jerusalem, The Library of Greek

Orthodox Church

Greece, Mount Athos, Koutloumousiou Kutl. 18

monastery

Greece, Mount Athos, Koutloumousiou Kutl. 49

monastery

England, London, The British Library

Italy, Florence, Laurentian Library

Italy, Florence, Laurentian Library

Egypt, Mount Sinai, Saint Catherine's

Monastery

Italy, Turin, The National and University

Library

Italy, Gevoa, Franzoniana Library

Italy, Vatican City, Apostolic Library

Italy, Vatican City, Apostolic Library

Italy, Milan, Biblioteca Ambrosiana
Conv. Soppr. 116

Grott. B.d. 29

Signature

Iber. 415

Sinod.gr. 313

Paris 1069

EBE 307

$E B E 308$

EBE 2210

RNB 86

Conv. Soppr. 162

Dem. 15

Jer. Saba 157

Lond. 17471

Plut. 09. 03

Plut. 89 sup. 22

Sin. gr. 417

Tor. C. III. 11

Urb. 29

Vat. Chig.gr. 7

Vat. gr. 2059

Mil. E 108 sup. 
According to Pinakes database, EBE Met. 857 is written in 10th-11th century. I did not include it in this list, because the manuscript represents a Sammelband (convolutus) from 4 parts, and the Ladder is dated by 11th century.

One has to conclude that the ancient manuscripts of the Ladder are investigated in extremely insufficient way. Almost no manuscript was included into scientific circulation Iber. 1434, Karak. 29, EBE 307, EBE 308, EBE 2210, RNB 86, Dem. 15, Kutl.18, Kutl. 49, Tor. C. III. 11, Grott. B.d. 29. For many years till now the hypothesis, that $\operatorname{Sin} . g r .416$ and $R N B 86$ are two parts of the same manuscript, is not proved.

The most ancient Greek manuscripts of the Ladder are available in the libraries of approximately 8 countries, a big part is kept in the collections of Italy (12 books) and Greece (10 books). 4 manuscripts are kept in the libraries of Egypt as well as in Russia, 2 - in England, 1 - in Germany, in France and in Israel (Jerusalem). The manuscripts were created in Halki (Bar.134), in Vatopedi (Sinod. gr. 313), and in Capua (Paris 1069). From 35 manuscripts 6 manuscripts have the exact dating by the scribers.

Chronological distribution of the most ancient manuscripts of the Ladder (eighth century -2 , ninth century -4 , tenth century -29 ) shows a strong increase of interest towards the book after the ninth century. Since that time, John Climacus became revered as Saint in the Byzantine church.

The most ancient manuscripts with interpretations are Jer. Saba 157, Sin. gr. 421, Urb. 29.

Among the owners of these books there were such great historical personalities as the French politician Jean-Baptiste Colbert (Paris 1069), the Italian scientist and writer Jacopo Gaddi (Plut. 89 sup. 22), and the German merchant Ulrich Fugger the Elder (Vat. Palat. gr. 49).

The most ancient manuscripts of the Synodal collection of the State Historical Museum (Sinod. gr. 145, Sinod. gr. 313, Sinod. gr. 362) were delivered to Moscow from the Athos monasteries by Arseniy Sukhanov.

Many of the Greek manuscripts of the Ladder are beautifully illustrated. The catalogue of illustrated Greek books of the Ladder contains 33 names. ${ }^{5}$ And manuscripts may contain not one but many beautiful images (for example, the manuscript at Princeton University library (Garrett 16) is illustrated with 43 miniatures). There is an opinion that the first illustrated manuscripts of the Ladder appeared not earlier than in the 11 th century. ${ }^{6}$ This is not correct. The

5 J. R. Martin, The Illustration of the Heavenly Ladder of John Climacus (Studies in Manuscript Illumination, 5), Princeton, 1954, pp. 164-192.

6 A. P. Kazhdan, "John Klimax," in: The Oxford Dictionary of Byzantium, vol. 2, New York, 1991, p. 1061. 
tradition of illustrating the manuscripts of the Ladder with pictures and miniatures began in the 1oth century. Such manuscripts as Iber. 415, Paris 1069, Vat. Chig. gr. 7, Sin. gr. 417 are illustrated, and Sin. gr. 417 has kept not one but three miniatures.

Of these 35 manuscripts 13 ones are "Ladder with additions" (Sammelbands). The scribes of the manuscripts combined the text of the Ladder and the works of other authors in one book. The works of Basil of Caesarea $(E B E$ 307, Jer. Saba 157, Mil. E 108 sup., Vat. gr. 2059) and Diadochos of Photiki (Sinod. gr. 145, Dem. 15, Jer. Saba 157, Vat. Chig. gr. 7) are most frequently included together with the Ladder. The works of Nilus of Sinai (Vat. Palat. gr. 49, Jer. Saba 157, Kutl. 18), Mark of Egypt (Sinod. gr. 145, Dem. 15, Jer. Saba 157), Dorotheus of Gaza (Sin. gr. 416, Vat. Chig. gr. 7), Ephrem the Syrian (Dem. 15,Jer. Saba 157) are a little bit more uncommon in ancient books. The books with the most ancient texts of the Ladder could also include the works of Ammon Monk (Jer. Saba 157), Amphilochius of Iconium (Kutl. 49), Anastasius Sinaita (Dem. 15), Athanasius of Alexandria (Jer. Saba 157), Gregory Thaumaturgus (Jer. Saba 157), Evagrius Ponticus (Vat. Palat. gr. 49), John of Damascus (Jer. Saba 157), John Chrysostom (Dem. 15), Isaac of Nineveh (Jer. Saba 157), John Cassian (Kutl. 18), Maximus the Confessor (Vat. Palat. gr. 49), Nikephoros I of Constantinople (Dem. 15), Thalassios of Libya (Kutl. 18) and Theodore the Studite (Jer. Saba 157). Vat. Palat. gr. 49 has kept the fragments from the Triodion.

A scientific critical modern edition of the Greek text of the Ladder is not present. The best, in fact, is the publication of Jesuit Matthew Rader dedicated to Cardinal Richelieu (S. Ioannis Scholastici, abbatis Montis Sina, qui vulgo Climacus appelatur, opera omnia, Interprete Matthaeo Radero, Lutetiae - Parisiorum, 1633). This edition is at the moment practically inaccessible. For this edition Rader used 7 manuscripts from Munich and one manuscript from Antwerp, the destiny of which is unknown. This edition (with some corrections) is reprinted in 1860 in Paris (Climaci Joannis Scala paradise, in PG 88, col. 5831248). In 1941 in Turin P. Trevisan has republished the text of the J. P. Migne with a parallel Italian translation (S. Giovanni Climaco Scala paradise, testo con introduzione, versione e note del Sac. Pietro Trevisan (Corona patrum Salesiana. Series graeca, VIII, IX)). A new edition of the Ladder was published in Constantinople in 1883, prepared by the monk of Great Lavra (Athos) Sophronius, for which the editor used a manuscript (which is unknown) of Dionisiou Monastery. A further new edition of the Ladder was issued in Oropos (Greece) in 1978, with a Modern Greek translation and commentaries prepared by Archimandrite Ignatius. The manuscript from monastery Stavronikita (cod. $\mathrm{Nr}_{50}$ ) and the edition of Sophronius serve as two bases of this edition. This version of the Greek text of the Ladder is constantly republished. Thus, there are known 
three printed versions of the Greek text of the Ladder: of Rader (Migne, Trevisan), of Sophronius, and of Ignatius. (None of these books takes into consideration the texts of the above-mentioned oldest Greek manuscripts of the Ladder.)

The general picture of Byzantine hand-written tradition of the Ladder would be incomplete without mentioning the ascetic Sammelbands into which structure the authors included fragments of the text of the Ladder. Among the most ancient ascetic Sammelbands with fragments of the Ladder are Jer. Saba 605, Mil. S. P. 6.14, Mil. Q 74 sup., Ven. 23.

So, now it is possible to talk about the existence of 35 Greek manuscripts of the Ladder of Saint John Climacus from the eighth to the tenth century included into the scientific circulation. The author will be very grateful to everyone who can give any information, which may help her in finding or identification of the oldest Greek manuscripts of the Ladder, and also for remarks, notes and additions. 